\title{
Suppression of epithelial apoptosis and delayed mammary gland involution in mice with a conditional knockout of Stat3
}

\author{
Rachel S. Chapman, ${ }^{1}$ Paula C. Lourenco, ${ }^{1}$ Elizabeth Tonner, ${ }^{2}$ David J. Flint, ${ }^{2}$ Stefan Selbert, ${ }^{1}$ \\ Kiyoshi Takeda, ${ }^{3}$ Shizuo Akira, ${ }^{3}$ Alan R. Clarke, ${ }^{1}$ and Christine J. Watson ${ }^{1,4}$ \\ ${ }^{1}$ Cancer Research Campaign (CRC) Laboratories, Department of Pathology, University of Edinburgh, Medical School, \\ Edinburgh EH8 9AG UK; ${ }^{2}$ Hannah Research Institute, Ayr, Scotland KA6 5HL UK; ${ }^{3}$ Department of Host Defence, Research \\ Institute for Microbial Diseases, Osaka University, Suita, Osaka 565-0871, Japan
}

\begin{abstract}
Mammary gland involution is characterized by extensive apoptosis of the epithelial cells. At the onset of involution, Stat 3 is specifically activated. To address the function of this signaling molecule in mammary epithelial apoptosis, we have generated a conditional knockout of Stat3 using the Cre-lox recombination system. Following weaning, a decrease in apoptosis and a dramatic delay of involution occurred in Stat3 null mammary tissue. Involution is normally associated with a significant increase in IGFBP-5 levels. This was observed in control glands, but not in the absence of Stat3. IGFBP-5 has been suggested to induce apoptosis by sequestering IGF-1 to casein micelles, thereby inhibiting its survival function. Our findings suggest that IGFBP-5 is a direct or indirect target for Stat 3 and its upregulation is essential to normal involution. No marked differences were seen in the regulation of Stat5, Bcl- $x_{L}$, or Bax in the absence of Stat3. Precocious activation of Stat1 and increases in levels of $\mathrm{p} 53$ and p21 occurred and may act as compensatory mechanisms for the eventual initiation of involution observed in Stat 3 null mammary glands. This is the first demonstration of the importance of a Stat factor in signaling the initiation of physiological apoptosis in vivo.
\end{abstract}

[Key Words: Stat3; conditional knockout; apoptosis; mammary involution]

Recieved March 1, 1999; accepted in revised form August 4, 1999.

Stats (signal transducer and activator of transcription) are a family of latent transcription factors that are activated in response to many cytokines and growth factors (Ihle 1996). They are activated by phosphorylation on a specific tyrosine residue, usually by receptor-associated JAKs (Janus kinases). Activated Stats form homo- or heterodimers and translocate to the nucleus in which they interact with consensus promoter sequences and regulate transcription. Initial cell culture studies showed that various combinations of Stats are involved in mediating a variety of growth and differentiation signals. More recently, Stats have been implicated in signaling apoptosis and survival.

The induction of apoptosis by Stats has been investigated in different in vitro systems. Overexpression of wild-type Stat3-accelerated IL-6 or LIF-induced apoptosis in myeloid leukaemia cells, whereas dominant-negative Stat3 blocked growth arrest and apoptosis induced by these cytokines (Minami et al. 1996). Stat3 was also re-

\footnotetext{
${ }^{4}$ Corresponding author. Present address: Department of Pathology, University of Cambridge, Cambridge CB2 1QP UK.

E-MAIL cjw53@mole.bio.cam.ac.uk; FAX 441223333346.
}

quired for induction of apoptosis after MHC-1 ligation on T cells (Skov et al. 1998). However, the association between Stats and apoptosis is not limited to Stat3. Stat1-deficient cells have been shown to be resistant to TNF $\alpha$ - (Kumar et al. 1997) and IFN- $\gamma$-induced apoptosis (Chin et al. 1997) and a naturally occurring dominantnegative mutant of Stat 5 rendered cells resistant to apoptosis (Bovolenta et al. 1998).

Conversely, but not surprisingly, suppression of apoptosis can also depend on Stat activity. Stat3 was shown to be required for gp-130 receptor-induced suppression of apoptosis in a pro-B cell line (Fukada et al. 1996), and IL-2-induced survival of 32D myeloid cells was Stat5 dependent (Zamorano et al. 1998). Induction of expression of $B c 1-2$, an apoptosis suppressor, was dependent on Stat3, but not Stat5, in these systems. Constitutive activation of Stat 3 in human myeloma cells suppressed apoptosis and induced expression of Bcl- $\mathrm{x}_{\mathrm{L}}$ (Catlett-Falcone et al. 1999). In vivo studies with T-cell-specific Stat3-deficient mice have shown that Stat3 is required for the Bcl-2-independent survival of $\mathrm{T}$ cells in response to IL-6 (Takeda et al. 1998). The role of Stat factors in the regulation of apoptosis is thus cell type specific and 
due to activation or suppression of a variety of target genes.

The availability of knockout mice has allowed a more precise clarification of the role of individual Stat factors in tissue homeostasis. This has been dramatically shown in the Stat5a knockout mouse that was phenotypically normal with the exception of the mammary gland, which failed to develop during pregnancy and lactate (Liu et al. 1997; Teglund et al. 1998). Stat5 is activated during pregnancy and lactation but is rapidly down regulated during involution (Liu et al. 1996; Philp et al. 1996). Conversely, Stat3 is specifically activated at the start of involution (Liu et al. 1996; Philp et al. 1996), which is characterized by removal of epithelial cells by apoptosis (Walker et al. 1989; Strange et al. 1992). The reciprocal activation of Stats 3 and 5 at the onset of apoptosis suggests opposing roles for these Stats in the regulation of apoptosis in the mammary gland. Stat 1 is also implicated in remodeling of the mammary gland during involution, as it becomes activated in the later stages of this process (Liu et al. 1996).

To determine the involvement of Stat 3 in regulating apoptosis and involution in the mammary gland, it was necessary to generate a tissue-specific, conditional knockout of Stat3 to overcome the early embryonic lethality of Stat3 disruption (Takeda et al. 1997). We have achieved this result using the Cre-lox recombination system in which expression of Cre recombinase is di- rected specifically to mammary epithelial cells by the promoter of the milk protein gene $\beta$-lactoglobulin (BLG) (Selbert et al. 1998). These BLG-Cre transgenic mice were crossed with mice containing one null Stat3 allele and one floxed Stat3 allele in which the loxP sites were inserted around the tyrosine phosphorylation domain to create a functional knockout of Stat3 (Takeda et al. 1998). The mice exhibited suppression of epithelial apoptosis and delayed involution. This is the first description of a role for a Stat factor in the induction of apoptosis in vivo.

\section{Results}

Analysis of Stat 3 expression in the mammary glands of knockout mice

Mice expressing BLG-Cre and either one floxed Stat3 and one wild-type Stat3 allele (BLG-Cre/Stat $3^{\text {flox/++}}$ ) or one floxed Stat3 and one null Stat3 allele (BLG-Cre/ Stat $3^{\text {flox/- }}$ - reached adulthood with no apparent abnormalities. Figure 1A shows a Southern blot used to characterize the extent of BLG-Cre-mediated recombination occurring at the floxed Stat3 allele at day 10 of lactation. Following digestion with HindIII and by use of a probe that spans exons 16-17 of Stat3 (Takeda et al. 1998), wild-type Stat3 was detected as an 8-kb fragment (lane 1), the floxed unrecombined Stat3 allele as an 8-kb frag-

$\mathbf{A}$
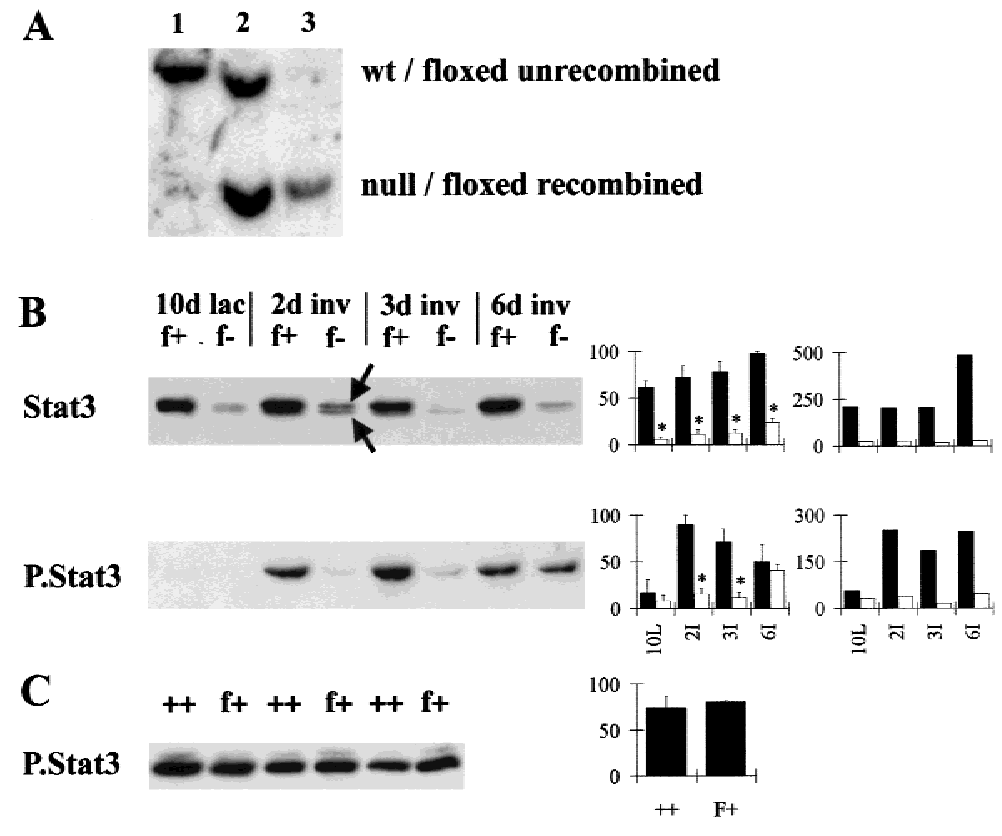

Figure 1. Deletion of Stat 3 in the mammary gland of BLG-Cre/Stat $3^{\text {flox } /-}$ mice. (A) Southern analysis of Stat3. (Lane 1) Wild-type DNA; (lane 2) DNA from floxed/null liver (not recombined); (lane 3) DNA from floxed/null mammary gland (recombined). (B) Western blot analysis of protein extracted from mammary glands, $20 \mu \mathrm{g}$ of protein/lane. Western blots show total Stat3 and phosphorylated Stat3 (P.Stat3) at day 10 of lactation (lac, L) and days 2, 3, and 6 of involution (inv, I). (Graph left) Densitometry analysis for 3-4 independent mice, mean \pm S.E.M. calculated as a percentage of the highest value for each blot; (graph, right) values relative to keratin 18 calculated as a proportion of the mean (hence, no error bars are included). Solid bars $(\mathrm{f}+)$ BLG-Cre $/$ Stat $3^{\text {flox } /+}$ (open bars) (f-) BLG-Cre/Stat3 ${ }^{\text {flox/- }}$; (arrows) full-length and $\Delta$ Stat3. $(C)$ Western blotting for phosphorylated Stat 3 at day 2 of involution in BLG-Cre/Stat $3^{\text {flox/+ }}$ $(\mathrm{f}+)$ and wild-type Stat3 $(++)$ glands, (shown for three independent mice). Graph shows densitometry analysis. $(D)$ EMSA with a Stat-specific site at day 2 of involution. (Lanes 1-4) BLG-Cre/Stat $3^{\text {flox } /+}$; (lanes 5-8) BLG-Cre/Stat3 ${ }^{\text {flox/- }}$; (lanes 1,5$)$ no supershift; (lanes 2,6) Stat1 supershift; (lanes 3,7) Stat3 supershift; (lanes 4,8) Stat5 supershift. 
ment and the null Stat3 allele as a 4.1-kb fragment (lane 2). BLG-Cre mediated recombination within the mammary gland of a BLG-Cre/Stat $3^{\text {flox/- }}$ mouse was evidenced by loss of the 8-kb fragment (lane 3) and appearance of a 4.1-kb fragment. Quantification of the loss of the 8 -kb fragment using a PhosphorImager showed that recombination occurred with an efficiency of $82 \%$, a figure that correlates well with our previous results using the BLG-Cre strain (Selbert et al. 1998). This compares very favorably with other transgenic Cre strains (Xu et al. 1999).

The level of Stat 3 protein in the mammary gland was measured by Western blot analysis. Figure 1B shows a representative Western blot for levels of Stat3 in mammary tissue from day 10 lactating gland, and days 2, 3, and 6 of involution, with densitometry analysis of results from three independent mice. In BLG-Cre/ Stat $3^{\text {flox/+ }}$ mice, high levels of Stat 3 were found in the mammary gland at all time points with an increase during involution. In glands from BLG-Cre/Stat $3^{\text {flox/- }}$ mice, levels of Stat 3 were greatly reduced at all time points. Levels of protein were standardized relative to the most intense band observed in each Western blot, permitting comparison between different Western blots. For example, at day 10 of lactation, glands from BLG-Cre/ Stat $3^{\text {flox } /+}$ mice contained $61 \% \pm 7 \%$ and BLG-Cre/ Stat $3^{\text {flox } /-}$ glands contained $6 \% \pm 2 \% \quad(n=3$ mean \pm S.E.M.) relative to the highest level of Stat 3 observed over the time course. The extent of reduction in Stat 3 levels agrees well with both the Southern data and previous data (Selbert et al. 1998). An increase in Stat3 levels during involution was also seen in BLG-Cre/ Stat $3^{\text {flox/- }}$ glands. The amount of Stat 3 was also calculated relative to the level of keratin 18, a marker of epithelial cells (Fig. 1B; see Fig. 6, below for quantification of the level of keratin 18 in the mammary gland). In BLG-Cre/Stat $3^{\text {flox/+ }}$ glands, the relative level of Stat 3 remained constant until day 6 , when an increase relative to keratin 18 was seen. In BLG-Cre/Stat $3^{\text {flox/- }}$ glands, the level of Stat 3 relative to keratin 18 remained low and constant throughout involution.

A lower band was seen in both BLG-Cre/Stat $3^{\text {flox/+ }}$ and BLG-Cre/Stat $3^{\text {flox/- }}$ glands (the upper and lower bands are indicated by arrows in Fig. 1B), corresponding with the previously observed truncated Stat3 protein $(\operatorname{Stat} 3 \Delta)$ generated as a result of deletion of the floxed domain (Takeda et al. 1998). The levels of Stat $3 \Delta$ in both BLG-Cre $/$ Stat $3^{\text {flox } /+}$ and BLG-Cre $/$ Stat $3^{\text {flox } /-}$ mice were much reduced compared with the level of wild-type Stat3 in BLG-Cre/Stat $3^{\text {flox/+ }}$ mice, suggesting that the truncated RNA or protein is unstable.

To establish the cellular localization of Stat3 during involution, we performed immunohistochemistry on sections of mammary gland. Figure 2 shows samples from day 2 of involution. Stat3 immunostaining was seen in both the nucleus and cytoplasm of epithelial cells lining the alveoli (BLG-Cre/Stat $3^{\text {flox/+ }}$ mice, Fig. 2A). In contrast, Stat 3 immunostaining was lost from the vast majority of cells in BLG-Cre/Stat ${ }^{\text {flox/- }}$ mice (Fig. 2B), although occasional positive cells were seen. These represent either nonepithelial cells or rare epithelial cells that have not undergone recombination.

Stat $3 \Delta$ cannot be activated because of loss of the critical tyrosine residue that is phosphorylated. In thymocytes, this truncated protein functioned as a dominant negative, preventing IL-6-induced activation of wild-type Stat3 in Lck-Cre/Stat $3^{\text {flox/+ }}$ mice (Takeda et al. 1998). However, this was not the case in mice with a keratinocyte-specific deletion of Stat3 (S. Sano, pers. comm.) suggesting that the ability of Stat $3 \Delta$ to function as a dominant-negative is cell- and stimulus-type specific. To establish whether Stat $3 \Delta$ functions as a dominant-negative in the mammary gland, we examined the activation of Stat3 during involution using an antibody to phosphorylated Stat3 (Fig. 1B, P.Stat3). At day 10 of lactation, no phosphorylated Stat3 could be detected. By day 2 of involution, there was phosphorylation of Stat3 in BLGCre/Stat $3^{\text {flox/+ }}$ mice that continued through to day 6 . In BLG-Cre/Stat $3^{\text {flox/- }}$ mice, very little phosphorylated Stat 3 could be detected until day 6, when an increase was observed. Calculation of these results relative to keratin 18 showed that the level of phosphorylated Stat3 was high throughout involution in BLG-Cre/Stat $3^{\text {flox/+ }}$ glands and remained low in BLG-Cre/Stat $3^{\text {flox/- }}$ glands (Fig. 1B). The level of phosphorylated Stat3 in BLG-Cre/ Stat $3^{\text {flox/+ }}$ mice was indistinguishable from Stat3 wildtype mice at day 2 of involution (Fig. 1C), indicating that in the mammary gland, Stat $3 \Delta$ does not function to prevent the activation of wild-type Stat3.

Levels of Stat DNA-binding activity were measured in glands from both BLG-Cre/Stat $3^{\text {flox/+ }}$ and BLG-Cre/ Stat $3^{\text {flox/- }}$ mice by EMSA using a consensus Stat DNAbinding site from the BLG promoter (Fig. 1D). Glands from day 2 of involution contained Stat-binding activity (lanes 1 and 5). Following treatment with an antibody to Stat3 (lanes 3 and 7) DNA-binding activity was still ap-

Figure 2. Deletion of Stat 3 in mammary epithelial cells of BLG-Cre/Stat $3^{\text {flox/- }}$ mice. Immunohistochemistry for Stat 3 protein at day 2 of involution in BLG-Cre/Stat $3^{\text {flox/+ }}$ mammary glands $(A)$ and BLG-Cre/Stat ${ }^{\text {flox } /-}$ mammary glands $(B)$. Scale bar, $25 \mu \mathrm{m}$. (Inset) High power magnification. Scale bar, $10 \mu \mathrm{m}$.
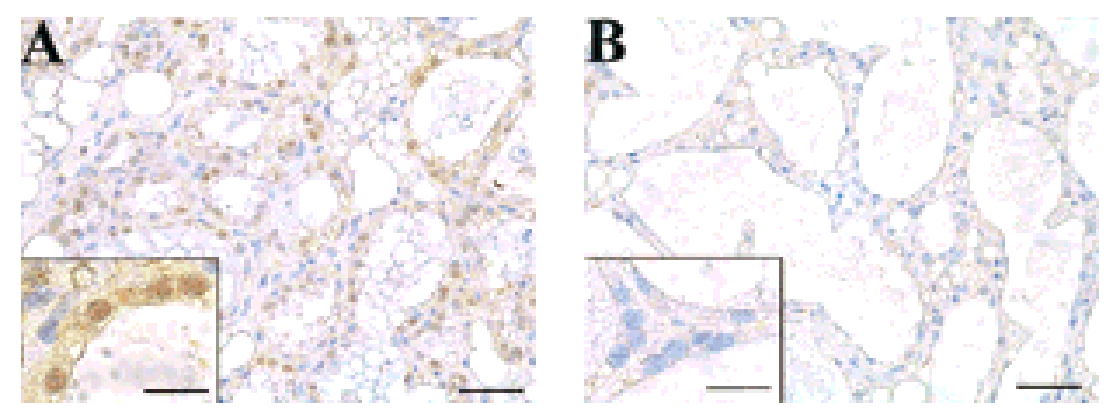
parent in BLG-Cre/Stat $3^{\text {flox/+ }}$ and BLG-Cre/Stat $3^{\text {flox/- }}$ glands. Treatment with an antibody to Stat5 resulted in supershift from both BLG-Cre/Stat $3^{\text {flox/+ }}$ and BLG-Cre/ Stat $3^{\text {flox/- }}$ glands, indicating the presence of activated Stat5 (lanes 4 and 8). Following the Stat5 supershift, a band remained in the BLG-Cre/Stat $3^{\text {flox/+ }}$ gland, which has been shown previously to be Stat3 (Philp et al. 1996). No such band was seen in BLG-Cre/Stat $3^{\text {flox/- }}$ glands, confirming the loss of Stat3.

\section{Deletion of Stat3 in the mammary gland resulted in delayed involution}

Figure 3 shows hematoxylin- and eosin-stained sections of BLG-Cre/Stat $3^{\text {flox/+ }}$ (A,C,E,G) and BLG-Cre/Stat $3^{\text {flox/- }}$ $(\mathrm{B}, \mathrm{D}, \mathrm{F}, \mathrm{H})$ mammary glands during lactation and involution. At day 10 of lactation, the majority of the gland was composed of alveoli lined by epithelial cells that secrete milk components into the alveolar lumina. No phenotypic difference was detected between BLG-Cre/Stat $3^{\text {flox/+ }}$ (Fig. 3A) and BLG-Cre/Stat $3^{\text {flox/- }}$ (Fig. 3B) mice at this stage. No differences were observed in the ability of

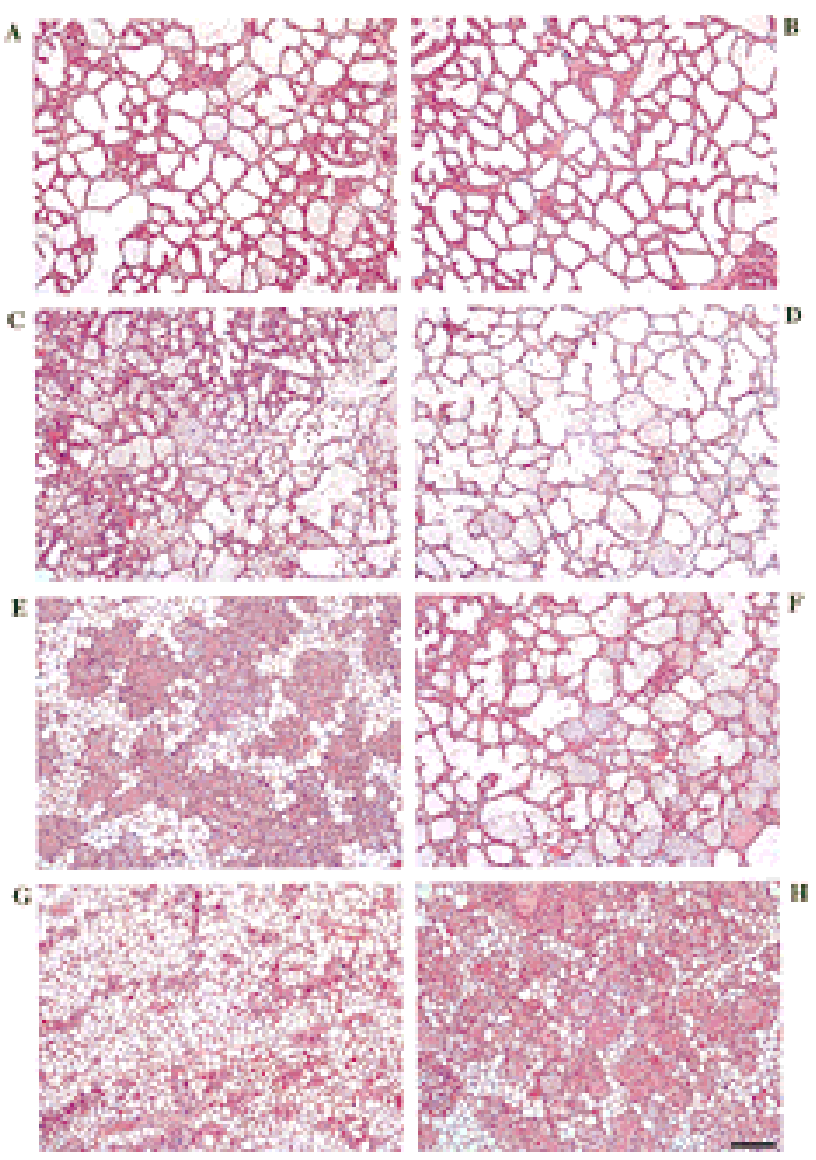

Figure 3. Delayed involution in BLG-Cre/Stat $3^{\text {flox/- }}$ mammary glands. $(A, C, E, G)$ BLG-Cre/Stat $3^{\text {flox } /+}$ mammary glands; $(B, D, F, H)$ BLG-Cre/Stat3 ${ }^{\text {flox/- }}$ mammary glands; $(A, B)$ day 10 of lactation; $(C, D)$ day 2 of involution; $(E, F)$ day 3 of involution; $(G, H)$ day 6 of involution. Scale bar, $100 \mu \mathrm{m}$.

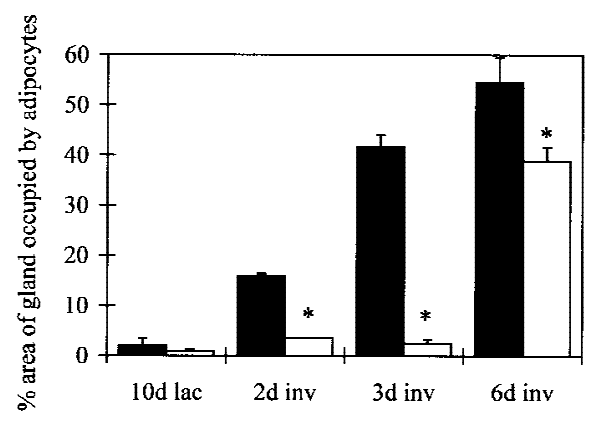

Figure 4. Delayed reappearance of adipocytes in BLG-Cre/ Stat $3^{\text {flox} /-}$ mammary glands. Each bar represents the mean of data collected from three mice, (solid bars) BLG-Cre/Stat $3^{\text {flox } /+}$; (open bars) BLG-Cre/Stat $3^{\text {flox } /-}$. Error bars represent standard error of the mean. $\left(^{\star}\right) p<0.05$ Mann-Whitney U test; (lac) lactation; (inv) involution.

BLG-Cre/Stat ${ }^{\text {flox/- }}$ mice to feed and maintain their litters compared with BLG-Cre/Stat $3^{\text {flox/+ }}$ mice.

By day 2 of involution, the alveoli of BLG-Cre/ Stat $3^{\text {flox/+ }}$ glands had started to collapse and apoptotic epithelial cells accumulated in the remaining open lumina (Fig. 3C). The alveoli of the BLG-Cre/Stat ${ }^{\text {flox/- }}$ animals remained intact and distended (Fig. 3D), and although a small number of apoptotic cells were seen, the gland retained the general appearance of a lactating gland.

At day 3 of involution, extensive tissue remodeling was apparent in glands from BLG-Cre/Stat $3^{\text {flox } /+}$ mice (Fig. 3E). The majority of the lobuloalveolar structure had collapsed, leaving mainly ducts, vessels, and clusters of epithelial cords, some with small lumina. A reappearance of adipocytes was seen, which constitute the majority of tissue in a resting gland. In contrast, involution was not apparent in the BLG-Cre/Stat $3^{\text {flox/- }}$ mice, the gland still being composed of intact alveolar structures and very little fat (Fig. 3F).

By day 6 of involution, the majority of the alveolar structure in the BLG-Cre/Stat $3^{\text {flox/+ }}$ mice had been remodeled with only occasional epithelial cords and ducts remaining, surrounded by stroma and adipocytes (Fig. $3 G)$. The glands in the BLG-Cre/Stat ${ }^{\text {flox/- }}$ mice had started to involute, but some of the alveoli were still intact (Fig. $3 \mathrm{H}$ ) and the gland resembled that of a day-3 BLG-Cre/Stat $3^{\text {flox/+ }}$ mouse (Fig. 3 cf. H with E).

To quantify the amount of involution that had occurred, the area of the gland occupied by adipocytes was measured and is shown in Figure 4. A significantly greater area was occupied by adipocytes in glands from BLG-Cre/Stat $3^{\text {flox/+ }}$ mice compared with BLG-Cre/ Stat $3^{\text {flox/- }}$ mice at all time points measured during involution (Mann Whitney U test, $P<0.05$ ). At day 3 of involution, mammary glands from BLG-Cre/Stat $3^{\text {flox } /+}$ mice were composed of $\sim 42 \%$ adipocytes compared with only $2 \%$ in BLG-Cre/Stat $3^{\text {flox/- }}$ mice reflecting the lack of morphological change seen in Figure 3. Taken together with the morphological appearance of the glands, these measurements suggest that at day 6 of involution, mam- 
mary glands from BLG-Cre/Stat $3^{\text {flox/- }}$ mice are phenotypically equivalent to those of day-3 BLG-Cre/Stat $3^{\text {flox/+ }}$ mice.

Delay of involution in the BLG-Cre/Stat $3^{\text {flox/- }}$ mice was accompanied by a dramatic increase in the incidence of mastitis. A total of 54\% (15 of 28) BLG-Cre/Stat $3^{\text {flox/- }}$ mice developed symptoms of mastitis compared with $3 \%(1$ of 30$)$ in BLG-Cre/Stat $3^{\text {flox/+ }}$ mice. Involution of the mammary gland is known to coincide with an increased susceptibility to mammary infection and mastitis (Nickerson 1989; Oliver and Sordillo 1989). This is probably due to milk stasis, a problem that is significantly enhanced in BLG-Cre/Stat $3^{\text {flox/- }}$ mice. Further studies on mastitis are currently underway and will be published elsewhere. All studies described here were performed in mice showing no overt or histopathological signs of mastitis.

\section{Decreased epithelial apoptosis in the absence of Stat3}

Involution is characterized by apoptosis of epithelial cells that can clearly be identified morphologically by their condensed chromatin (Wyllie et al. 1980; Walker et al. 1989). The observed delay of involution in BLG-Cre/ Stat $3^{\text {flox/- }}$ mice could be caused by decreased apoptosis. Apoptotic cells were seen shed into the lumina and also in the lobuloalveolar structure, in which they were usually decreased in size and detached from their neighbors (Fig. 5, top). Quantification of apoptosis assessed directly by morphology is shown in Figure 5 (top). Significantly less apoptosis was apparent by day 3 of involution in the BLG-Cre/Stat $3^{\text {flox/- }}$ mice $(1.9 \% \pm 0.2 \%)$ compared with the BLG-Cre/Stat $3^{\text {flox } /+}$ mice $(4.3 \% \pm 0.4 \%, n=3$, mean \pm S.E.M.. Mann-Whitney $U$ test, $P<0.05)$. Confirmation of this decrease in apoptosis in the absence of Stat 3 was performed by TUNEL analysis (Fig. 5 bottom). An increase in TUNEL positivity was seen at day 2 $(3.8 \% \pm 0.6 \%)$ and day $3(6.9 \% \pm 0.4 \%)$ of involution in the BLG-Cre/Stat $3^{\text {flox/+ }}$ mice. Significantly fewer cells were TUNEL positive in glands from BLG-Cre/ Stat $3^{\text {flox } /-}$ mice at these time points $(1.7 \% \pm 0.3 \%$ and
$2.9 \% \pm 0.2 \%$ respectively, mean \pm S.E.M., $n=3$, MannWhitney $U$ test, $P<0.05)$. A decrease in TUNEL positivity was seen at day 6 of involution in BLG-Cre/ Stat $3^{\text {flox/+ }}$ mice when the majority of the gland had been remodeled. A gradual increase in the number of TUNELpositive cells was seen up to day 6 in glands from BLGCre/Stat $3^{\text {flox/- }}$ mice in conjunction with the eventual involution seen.

\section{Molecular analysis of involuting mammary glands in the absence of Stat3}

Luminal epithelial cells are characterized by the presence of keratin 18 (Taylor-Papadimitriou and Lane 1987). Keratin 18 levels were examined and found to decrease in BLG-Cre/Stat $3^{\text {flox/+ }}$ glands by day 6 of involution (Fig. 6). BLG-Cre/Stat $3^{\text {flox } /-}$ glands contained the same level of keratin 18 at day 10 of lactation and at day 2 of involution, but at days 3 and 6 of involution, significantly higher levels were present. These results indicate that in the BLG-Cre/Stat $3^{\text {flox } /-}$ glands, the relative proportion of epithelial cell protein is increased. Presumably, this occurs as a direct consequence of reduced epithelial cell death and a reduced contribution from other proteins such as those found in milk (the contribution of milk proteins is described in more detail below).

At the start of involution, Stat 3 is activated and Stat5 is inactivated, suggesting reciprocal regulation between these molecules (Liu et al. 1996; Philip et al. 1996). Although both Stat5a and Stat5b are present in the mammary gland, Stat5a has been shown to be essential for normal mammopoeisis and lactogenesis (Liu et al. 1997; Teglund et al. 1998). We therefore investigated the levels of Stat5a in BLG-Cre/Stat $3^{\text {flox/- }}$ mice by Western blot analysis (Fig. 6). High levels were present in both BLGCre/Stat $3^{\text {flox/+ }}$ and BLG-Cre/Stat $3^{\text {flox/- }}$ mice at day 10 of lactation. By day 2 of involution, little Stat5a remained in BLG-Cre/Stat $3^{\text {flox/+ }}$ mice, with virtually none detectable at day 3 . In contrast, levels of Stat5a declined more slowly in BLG-Cre/Stat $3^{\text {flox/- }}$ mice with protein still detectable at day 2 and 3 . By day 6 , the level
Figure 5. Suppression of epithelial apoptosis in BLG-Cre/Stat $3^{\text {flox/- }}$ mammary glands. (Top) Morphological assessment of cells exhibiting condensed chromatin; (bottom) TUNEL analysis. Each panel shows a representative photograph at day 3 of involution and quantification of the results $(A)$ BLG-Cre/Stat $3^{\text {flox } /+}$; (solid bars), (B) BLG-Cre/Stat $3^{\text {flox } /-}$; (open bars). Each bar represents the mean of data collected from three mice. Error bars represent standard error of the mean; $\left(^{\star}\right) P<0.05$ MannWhitney U test; (lac) lactation; (inv) involution. Scale bar, $10 \mu \mathrm{m}$.
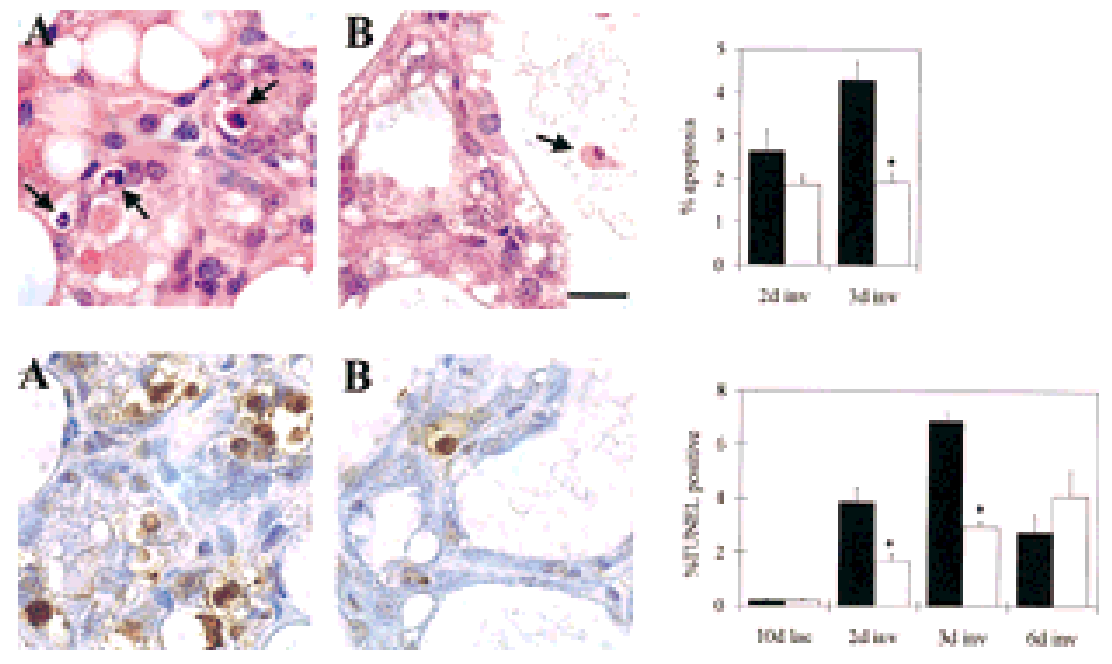


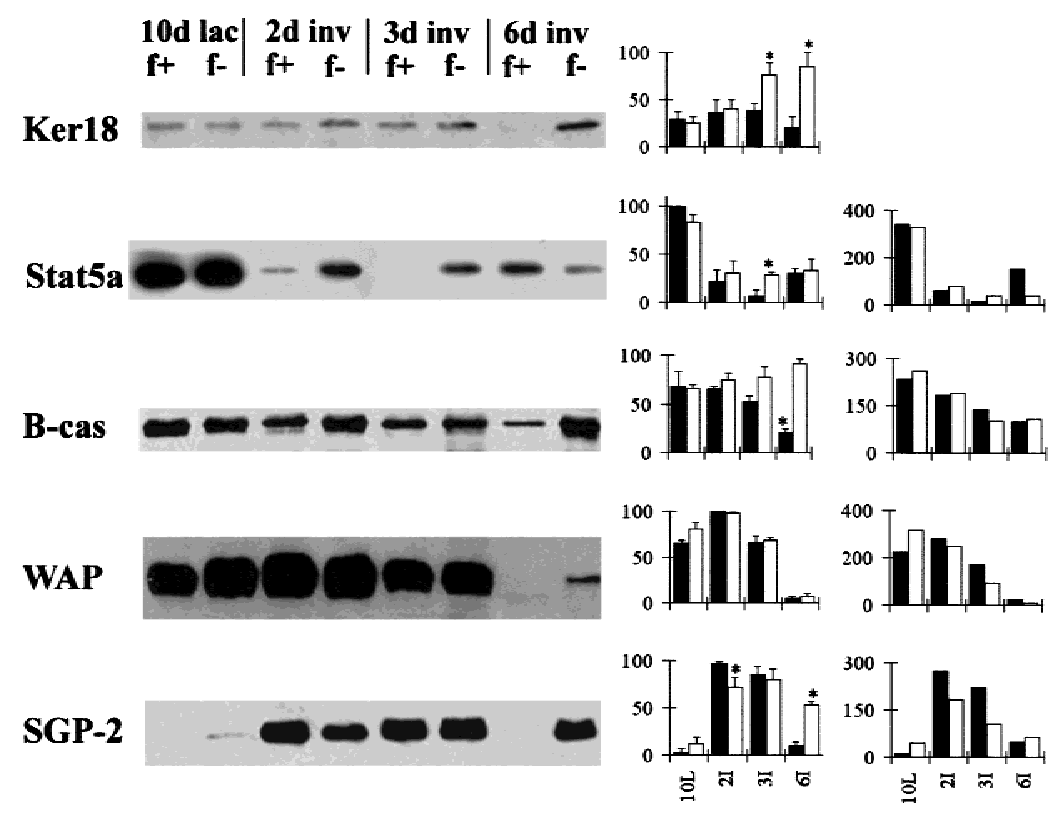

Figure 6. Analysis of molecular changes during involution by Western blot: $20 \mu \mathrm{g}$ protein/lane keratin 18 (Ker 18) and Stat5a; $5 \mu$ g protein/lane $\beta$-casein (B-cas), WAP and SGP-2 (clusterin) at day 10 of lactation (lac, L) and days 2, 3, and 6 of involution (inv, I). (Graph left Densitometry analysis for three independent mice, mean \pm sem calculated as a percentage of the highest value for each blot; (graph right) values relative to keratin $18 \mathrm{cal}-$ culated as a proportion of the mean (hence no error bars are included). $(\mathrm{f}+)$ BLG-Cre/Stat $3^{\text {flox } /+}$ (solid bars); (f-) BLG-Cre/Stat ${ }^{\text {flox/- }}$ (open bars). of Stat5a in BLG-Cre/Stat $3^{\text {flox/+ }}$ mice had started to increase, possibly reflecting the dramatic change in cell type in the involuting mammary gland. Quantification of these results relative to keratin 18 levels suggests that any difference seen between BLG-Cre/Stat $3^{\text {flox/+ }}$ and BLG-Cre/Stat $3^{\text {flox } /-}$ glands at day 2 and 3 is due to the presence of relatively more epithelial cells in BLG-Cre/ Stat $3^{\text {flox/- }}$ glands (Fig. 6). The DNA-binding activity of Stat5a/b also exhibited little difference during early involution as assessed by EMSA, in which similar levels of Stat 5 binding were observed in both BLG-Cre/Stat $3^{\text {flox/+ }}$ and BLG-Cre/Stat $3^{\text {flox } /-}$ mice at day 2 (Fig. 1D, lanes 4 and 8). However, Stat5 activity persisted until day 6 of involution in the BLG-Cre/Stat $3^{\text {flox/- }}$ mice /data not shown), presumably in the epithelial cells that had not undergone apoptosis.

Milk production ceases at the start of involution and as involution proceeds, the remaining milk in the gland is lost. To assess the differentiation status of glands in the absence of Stat3, levels of the milk proteins $\beta$-casein and WAP were measured (Fig. 6). $\beta$-Casein levels were significantly reduced in BLG-Cre/Stat $3^{\text {flox/+ }}$ glands by day 6 of involution, whereas levels in BLG-Cre/ Stat ${ }^{\text {flox/- }}$ glands remained high. In contrast, WAP levels had decreased by day 6 in both BLG-Cre/Stat ${ }^{\text {flox/+ }}$ and BLG-Cre/Stat $3^{\text {flox/- }}$ glands. When levels were calculated relative to the level of keratin 18, no difference was seen between BLG-Cre/Stat $3^{\text {flox/+ }}$ and BLG-Cre/Stat $3^{\text {flox/- }}$ glands. This suggests that the amount of milk protein remaining in the gland is directly proportional to the amount of epithelium, and higher absolute levels of $\beta$-casein seen in BLG-Cre/Stat $3^{\text {flox/- }}$ glands at day 6 are due to the continued presence of intact alveoli. The difference between $\beta$-casein and WAP levels at day 6 of involution could be due to differential regulation of these genes (Liu et al. 1997). These results also demonstrate that whereas BLG-Cre/Stat $3^{\text {flox/- }}$ glands at day 6 of in- volution morphologically resemble BLG-Cre/Stat $3^{\text {flox/+ }}$ glands at day 3 of involution, they are not identical at the molecular level.

One marker of involution is the up-regulated expression of SGP-2 (clusterin; Strange et al. 1992; Lund et al. 1996), although the role of this protein is unclear as it has been suggested to have both apoptosis-inducing and suppressing properties (Lakins et al. 1998). Measurement of SGP-2 in BLG-Cre/Stat $3^{\text {flox/+ }}$ glands revealed an increase during involution, peaking at day 2 (Fig. 6). Levels in BLG-Cre/Stat $3^{\text {flox/- }}$ glands also increased during involution and were maintained at day 6 . However, relative to keratin $18 \mathrm{BLG}-\mathrm{Cre} / \mathrm{Stat} 3^{\text {flox } /-}$ mice contained lower amounts of SGP- 2 than BLG-Cre/Stat $3^{\text {flox/+ }}$ mice.

\section{Stat1 levels and activity increased in the absence of Stat3}

Stat1 is normally activated during the late stages of involution (Liu et al. 1996) so it was of interest to determine whether BLG-Cre/Stat $3^{\text {flox/- }}$ mice had a delayed activation of Stat1. Western blot analysis of total and phosphorylated Stat1 is shown in Figure 7. Low levels of both isoforms of Stat1 (p84 and p91) were detected in lactating glands. An increase in Stat 1 levels was seen in BLG-Cre/Stat ${ }^{\text {flox/+ }}$ mice by day 6 of involution. BLGCre/Stat $3^{\text {flox/- }}$ mice also exhibited an increase in Stat 1 , but levels were significantly higher by day 2 , and further increased to day 6. Calculation of these results relative to keratin 18 revealed different kinetics for the increase with a peak in BLG-Cre/Stat $3^{\text {flox/- }}$ glands at day 2 in contrast to a peak at day 6 in BLG-Cre/Stat $3^{\text {flox } /+}$ glands. Two approaches were used to demonstrate that the increased levels of Stat1 were associated with increased activation; first, by Western analysis with an antibody to phosphorylated Stat1 (Fig. 7), which showed an increase in BLG-Cre/Stat $3^{\text {flox/- }}$ glands, and second, EMSA 
Chapman et al.

Figure 7. Regulation of Stat1 in the absence of Stat 3 measured by Western blot, $20 \mu$ g protein/ lane. Westerns show total Stat1 and phosphorylated Stat1 (P.Stat1) at day 10 of lactation (lac, L) and days 2, 3, and 6 of involution (inv, I). (Graph left) densitometry analysis of three independent mice, mean \pm sem calculated as a percentage of the highest value for each blot; (graph right) values relative to keratin 18 calculated as a proportion of the mean (hence, no error bars are included). $(\mathrm{f}+)$ BLG-Cre/Stat $3^{\text {flox } /+}$ (solid bars); $(\mathrm{f}-)$ BLG-Cre/Stat $3^{\text {flox } /-}$ (open bars).

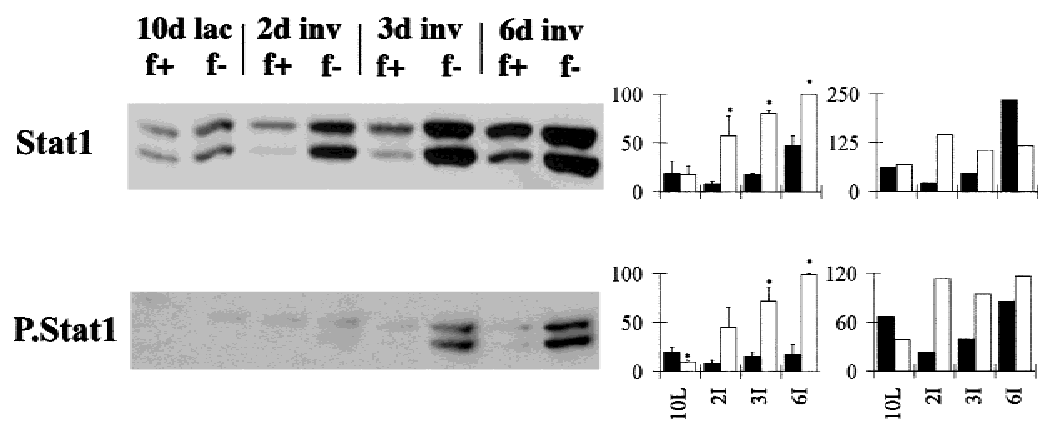

showed a band with higher mobility present in BLGCre/Stat $3^{\text {flox/- }}$ glands from day 2 of involution, which was supershifted by treatment with Statl antibody (Fig 1D lane 6 , cf. with no Stat1 in BLG-Cre/Stat $3^{\text {flox/+ }}$ glands, lane 2).

\section{Measurement of apoptosis-related proteins} in the absence of Stat3

Many changes in RNA and protein expression occur during involution. The reduced apoptosis seen in BLG-Cre/ Stat ${ }^{\text {flox/- }}$ mice prompted us to investigate the levels of apoptosis regulatory proteins (Fig. 8A). Bcl- $\mathrm{x}_{\mathrm{L}}$, which suppresses apoptosis in several systems (Adams and Cory 1998), has been shown to be up-regulated at the start of involution (Heermeier et al. 1996) and may prevent epithelial apoptosis during the initial phase of involution, allowing this phase to be reversed if necessary.
Western blot analysis of Bcl- $\mathrm{x}_{\mathrm{L}}$ showed a small increase in Bcl- $\mathrm{x}_{\mathrm{L}}$ in glands from BLG-Cre/Stat $3^{\text {flox/- }}$ at day 2 of involution compared with day 10 of lactation. There was no significant difference between BLG-Cre/Stat $3^{\text {flox/+ }}$ and BLG-Cre/Stat $3^{\text {flox/- }}$ mice at any of the time points examined (Mann Whitney U $P>0.05$ ). When these results were quantified relative to keratin 18 levels, the only difference was seen at day 6 of involution at which time levels of Bcl- $\mathrm{x}_{\mathrm{L}}$ in BLG-Cre/Stat $3^{\text {flox } /-}$ glands were significantly lower compared with BLG-Cre/Stat $3^{\text {flox/+ }}$ glands.

Bax, an inducer of apoptosis (Adams and Cory 1998), is also up-regulated at the start of involution and is thought to act as an apoptotic signal for epithelial cells (Heermeier et al. 1996). A decrease in Bax levels could therefore contribute to the delayed apoptosis seen in BLGCre/Stat $3^{\text {flox/- }}$ mice. Increased levels of Bax were detected in BLG-Cre/Stat $3^{\text {flox/+ }}$ glands during involution
Figure 8. Regulation of apoptosis-related proteins during involution. (A) Western blot analysis of Bcl- $\mathrm{x}_{\mathrm{L}}, \mathrm{Bax}, \mathrm{p} 53$ and $\mathrm{p} 21$ at day 10 of lactation (lac, L) and days 2, 3, and 6 of involution (inv, I), 20 ug protein/lane. (Graph left) densitometry analysis for three independent mice, mean \pm sem calculated as a percentage of the highest value for each blot, (graph right) values relative to keratin 18 calculated as a proportion of the mean (hence, no error bars are included). $(\mathrm{f}+)$ BLG-Cre/ Stat $3^{\text {flox } /+}$ (solid bars); (f-) BLG-Cre/Stat $3^{\text {flox } /-}$ (open bars). (B) IGFBP-5 Western ligand blot analysis showing mean and standard error of the mean of values from three or four independent mice. (Solid bars) BLG-Cre/Stat $3^{\text {flox/++}}$; BLG-Cre/ Stat ${ }^{\text {flox } /-}$ (open bars); $\left(^{*}\right) P<0.05$ Mann Whitney $\mathrm{U}$ test; (graph right) values relative to keratin 18 .

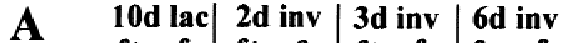

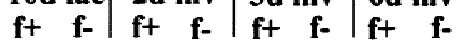

Bcl- $\mathbf{x}_{\mathbf{L}}$
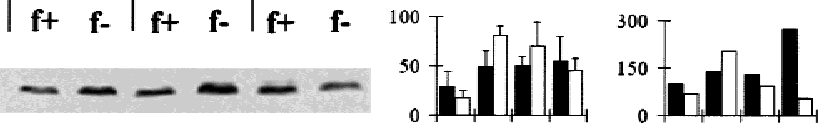

Bax
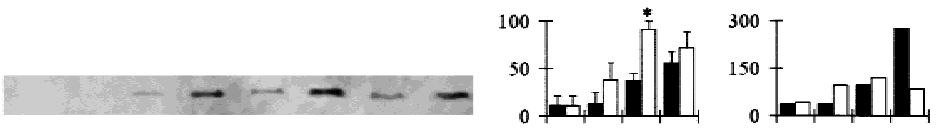

p53
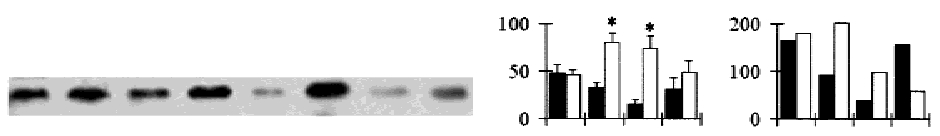

p21
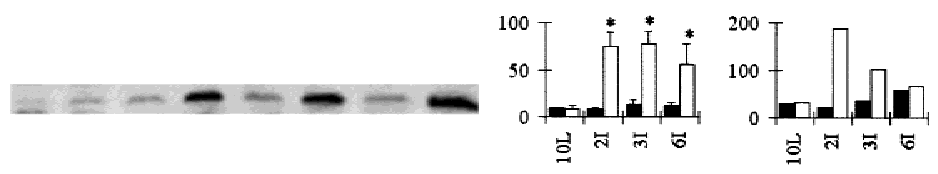

B
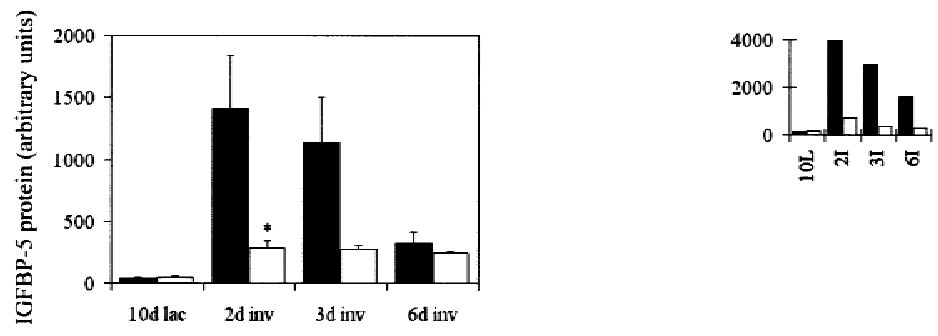
(Fig. 8A). Surprisingly, at day 3 of involution, the level of Bax was significantly higher in BLG-Cre/Stat $3^{\text {flox/- }}$ mammary glands compared with BLG-Cre/Stat $3^{\text {flox/+ }}$ (Mann Whitney $U$ test $P<0.05$ ). However, when considered relative to keratin 18 , this difference was not apparent at day 3, although an increase was observed in BLGCre/Stat $3^{\text {flox/+ }}$ glands at day 6 .

p53 mediates multiple functions including cell cycle arrest and apoptosis in response to cellular damage (Steele et al. 1998). An increase in p53 mRNA has been shown at the start of involution (Strange et al. 1992). p53 was detected in lactating glands of BLG-Cre/Stat $3^{\text {flox/+ }}$ mice, but decreased during early involution (Fig. 8A). In comparison, significantly higher levels were observed at days 2 and 3 of involution in BLG-Cre/Stat $3^{\text {flox/- }}$ mice (Mann Whitney $\mathrm{U}$ test $P<0.05$ ) (Fig. 8A). When quantified relative to keratin 18, levels of p53 at days 2 and 3 of involution were higher in BLG-Cre/Stat $3^{\text {flox/- }}$ glands compared with BLG-Cre/Stat $3^{\text {flox/+ }}$.

p21 mRNA increases during mammary gland involution in a p53-dependent manner (Jerry et al. 1998). p21 protein was detected at very low levels in BLG-Cre/ Stat $3^{\text {flox/+ }}$ mammary glands at all time points examined (Fig. 8A). A dramatic increase was seen in BLG-Cre/ Stat $3^{\text {flox/- }}$ mammary glands with similar kinetics to the increase in p53. Relative to keratin 18, p21 levels in BLG-Cre/Stat $3^{\text {flox/- }}$ glands were dramatically higher than BLG-Cre/Stat $3^{\text {flox/+ }}$ glands at day 2 of involution.

Levels of IGFBP-5 increase in milk during involution. IGFBP-5 is proposed to induce epithelial apoptosis by inhibiting IGF-1-mediated cell survival (Tonner et al. 1997). To establish whether IGFBP-5 levels were altered in the absence of Stat3, IGFBP-5 was detected by Western ligand blotting with radiolabeled IGF-1 (Fig. 8B). Compared with day 10 of lactation, a significant increase in IGFBP-5 was seen at day 2 of involution in BLG-Cre/ Stat $3^{\text {flox } /+}$ glands (Mann-Whitney $U, P<0.05$ ). In glands from BLG-Cre/Stat $3^{\text {flox/- }}$ mice a significantly smaller increase was observed at day 2 of involution $(P<0.05$, Mann-Whitney U). Calculation of these results relative to keratin 18 confirmed this difference.

\section{Discussion}

We have generated a conditional knockout of Stat 3 to examine the role of Stat3 during apoptosis and involution of the mammary gland. In agreement with previous data using the BLG-Cre transgenic strain (Selbert et al. 1998), we demonstrate very efficient deletion of lox Pflanked sequences in the lactating gland. BLG-Cre/ Stat $3^{\text {flox/- }}$ mice exhibited two- to threefold decreased levels of apoptosis and delayed involution compared with BLG-Cre/Stat $3^{\text {flox/+ }}$ mice, suggesting that activation of Stat 3 at the start of involution acts as an essential death signal for the gland. This level of difference in apoptosis is sufficient to explain the observed dramatic delay of involution seen, it has been shown previously that apoptosis occurring in $1 \%-2 \%$ of cells at any one time point can result in a $50 \%$ reduction of the total cell population over a 48-hr period (Howie et al. 1994).
Apoptosis is a morphologically defined phenomenon (Wyllie et al. 1980). We therefore scored apoptosis using the criterion of chromatin condensation. As an independent confirmation of these observations, we used TUNEL (e.g., Feng et al. 1995; Lund et al. 1996; Li et al. $1997)$ to detect DNA strand breaks. These two approaches yielded similar data, although TUNEL analysis did indicate a significant difference between BLG-Cre/ Stat $3^{\text {flox/+ }}$ and BLG-Cre/Stat $3^{\text {flox/- }}$ mice at day 2 of involution, which was not evident by morphological assessment. This difference may arise because TUNEL detects early-stage apoptosis prior to observable morphological change (Migheli et al. 1995), or because TUNEL may detect nonapoptotic events (deTorres et al. 1997; Stahelin et al. 1998). Significantly, we have used two independent methods to confirm a Stat3-dependent difference in the induction of apoptosis during involution. One advantage of TUNEL is its use during late involution (day 6), when apoptosis is difficult to score morphologically because of the invasion of inflammatory cells.

Interpretation of data obtained from the involuting mammary gland should take account of the dramatic tissue remodeling that is occurring. For this reason, we have examined the levels of keratin 18, a marker of luminal epithelial cells, to enable calculation of levels of protein relative to the epithelial content of the gland. We identified a subset of proteins that showed altered expression in the absence of Stat3 (e.g., Bax, $\beta$-casein) when analyzed at the level of the whole gland. However, when characterized relative to keratin 18 , these showed no such differences, implying that they were not differentially regulated within epithelial cells.

Stat3 levels increased during involution in glands from BLG-Cre/Stat ${ }^{\text {flox/+ }}$ mice. When calculated relative to keratin 18, the level of Stat3 increased at day 6 of involution, implying that the increase in Stat 3 levels seen at this point occurs as a consequence of invasion of the mammary gland by nonepithelial cells such as macrophages (Walker et al. 1989). An overall increase in the level of Stat3 was also seen in glands from BLG-Cre/ Stat $3^{\text {flox/- }}$ mice. It is unlikely that this was due to a small number of epithelial cells with unrecombined Stat 3 as these should have been removed by the normal program of apoptosis. When calculated relative to keratin 18, the level of Stat3 in BLG-Cre/Stat $3^{\text {flox/- }}$ glands remained low, indicating that the overall increase was not a consequence of increased expression in epithelial cells, but was probably due to the infiltration of inflammatory cells. The level of phosphorylated Stat3 decreased during late involution in glands from BLG-Cre/ Stat $3^{\text {flox/+ }}$ mice, indicating that although Stat 3 is present in the gland, less of the protein is in the active state. In contrast, the amount of phosphorylated Stat 3 increased at day 6 of involution in glands from BLG-Cre/ Stat $3^{\text {flox/- }}$ mice. Comparison with levels of keratin 18 suggested that this increase occurs in the nonepithelial component of the gland.

Stat5 activity is downregulated at the start of involution, although the importance of this remains equivocal, 
because the targets of Stat5a, other than WAP and possibly $\alpha$-lactalbumin, are not yet defined (Liu et al. 1997; Teglund et al. 1998). One possible function for Stat5 is as a survival signal for mammary epithelial cells. Treatment of mice with prolactin, which activates Stat5, has been shown to delay apoptosis and involution (Sheffield and Kotolski 1992; Travers et al. 1996). Stat5 has also been shown to be required for transduction of survival signals from the extracellular matrix (Streuli et al. 1995). It is tempting to speculate that Stat3 normally induces apoptosis by down-regulating Stat5. However, results presented here do not allow any conclusions to be made regarding a possible role for Stat5 in epithelial cell survival. The pattern of Stat 5 activation was perturbed in the null glands with continued activation of Stat5 observed until day 6 of involution in the BLG-Cre/ Stat $3^{\text {flox/- }}$ mammary tissue. Although this could account for the failure of these cells to undergo apoptosis, further work is required to clarify the significance of this observation. It is worth noting that Stat5a-deficient mice did not undergo a precocious involution, suggesting that Stat3 is able to signal apoptosis through alternative mechanisms to inactivating Stat5a (Liu et al. 1997). A reduction in Stat5a protein was seen during involution that has not been observed in another study (Liu et al. 1996). However, this previous study used inbred mice and different time points and may have missed any change that occurred. Also, the lack of difference observed in Stat5a protein levels is perhaps surprising considering that during involution the epithelial cells that express Stat5 die by apoptosis.

The Bcl-2 family of proteins are important regulators of apoptosis (Adams and Cory 1998). Bcl- $\mathrm{x}_{\mathrm{L}}$ and Bax have both been shown previously to be increased at the start of involution (Heermeier et al. 1996), Bcl- $X_{\mathrm{L}}$ has been shown previously to be up-regulated by Stat3 in myeloma cells (Catlett-Falcone et al. 1999). However, no such Stat3-dependent difference was observed in this study. Bax levels increased at the start of involution in BLG-Cre/Stat $3^{\text {flox/+ }}$ mice and a greater increase in Bax

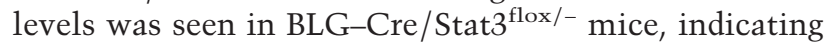
that Stat3 is not essential for the up-regulation of this protein. Standardization of these results relative to keratin 18 suggested that the increase in Bax in the absence of Stat3 was due to the presence of a greater number of surviving epithelial cells expressing Bax rather than an increase in the actual expression levels. The decision to enter apoptosis in the normal mammary gland may thus be influenced by other members of the Bcl-2 family and further investigation of these proteins could yield potential targets of Stat3.

IGF-1 is a potent mitogen for epithelial cells and has been shown to be a survival factor in vitro $/ \mathrm{O}^{\prime}$ Connor 1998). Transgenic animal studies have shown that overexpression of IGF-1 in the mammary gland delays involution (Hadsell et al. 1996; Neuenschwander et al. 1996), thus IGF-1 could act as an important survival factor for mammary epithelial cells. During involution, epithelial cells synthesize and secrete high levels of IGFBP-5 (Tonner et al. 1997). This increase was strongly suppressed in
BLG-Cre/Stat ${ }^{\text {flox/- }}$ mice. IGFBP-5 has been proposed to induce apoptosis by sequestering IGF-1 to casein micelles, thus preventing it from binding to its receptor. Low levels of IGFBP-5 would thus result in an increased biological potency of IGF-1, which in turn would suppress apoptosis and delay involution. Little is known about the regulation of IGFBP-5 transcription, and it remains unclear whether IGFBP-5 expression is directly dependent on Stat3 binding to the IGFBP-5 promoter. However, the human IGFBP-5 promoter does contain a consensus Stat-binding element (unpublished sequence, accession no. U20271) in addition to consensus sequences for AP-1, which increases dramatically during mammary involution (Feng et al. 1995), and AP-2 (Tenniswood et al. 1994; Duan and Clemmons 1995). It will be interesting to investigate the transcriptional regulation of IGFBP-5 and whether AP-1 is central to the mechanism by which Stat 3 regulates IGFBP- 5 .

In the absence of Stat 3 there must be compensatory mechanisms operating that eventually lead to involution, albeit with much delayed kinetics as by day 6 of involution the BLG-Cre/Stat $3^{\text {flox/- }}$ glands phenotypically resemble BLG-Cre/Stat $3^{\text {flox/+ }}$ glands at day 3 of involution. We have identified two candidates for this, Stat1 and p53. BLG-Cre/Stat $3^{\text {flox/- }}$ mice display an enhanced and earlier activation of Stat1. This Stat is normally induced late in involution and, although its role is as yet unclear, it is already known to be required for induction of apoptosis in some systems. Such induction may involve regulation of caspase levels although not through a direct transcriptional effect (Chin et al. 1997; Kumar et al. 1997). Evidence from knockout mice suggests that different Stat family members can compensate for each other. Stat1-deficient mice were unresponsive to IFN but did not display any difference in response to $\mathrm{GH}$, EGF, or IL-10, which activate Stats 1 and 3 (Meraz et al. 1996). This suggests that any role for Stat 1 in signaling from these cytokines may be compensated for by Stat3. The principle that different Stats can substitute for one another in gene regulation has been demonstrated by experiments in IL-4 treated T cells in which Stat5 target genes were regulated by Stat6 (Chida et al. 1998). However, there are many examples in which Stats are unable to compensate for one another and it remains to be seen whether Stat1 is signaling involution through the same or different targets to Stat3. The absence of any dramatic increase in IGFBP-5 once BLG-Cre/ Stat $3^{\text {flox/- }}$ glands have started to involute (day 6) indicates that an alternative mechanism operates in the absence of Stat3.

p53 has an established role in regulating apoptosis, but the role of p53 in mammary involution is unclear as involution proceeded normally in outbred p53 knockout mice (Li et al. 1996), but was delayed on a BALB/c background (Jerry et al. 1998). p53 is transcriptionally activated during mammary gland involution (Strange et al. 1992; Quarrie et al. 1996), although no increased protein levels were found in our BLG-Cre/Stat $3^{\text {flox/+ }}$ mice. However, we did observe an induction of p53 in the BLG-Cre/Stat $3^{\text {flox/- }}$ mice at days 2 and 3 of involution, 
which may signal the induction of apoptosis in the absence of Stat3. This difference in p53 was also apparent at day 2 when the level of p53 was calculated relative to that of keratin 18, suggesting that altered p53 regulation had occurred in the epithelial cells of BLG-Cre/ Stat $3^{\text {flox/- }}$ glands. One well-known target of p53 is p21, an inhibitor of cyclin dependent kinases (el-Deiry 1998). p21 levels were increased only in mammary glands from BLG-Cre/Stat $3^{\text {flox/- }}$ mice with similar kinetics to p53, suggesting it may be one target of p53 (although there are many examples of p53-independent regulation of $\mathrm{p} 21$ ). Stat3 has also been shown to down-regulate expression of p21 (Fukada et al. 1998). The precise role played by p21 in involution remains unclear; however, p21 may be required for the eventual induction of apoptosis (Duttaroy et al. 1997). Studies of BLG-Cre/Stat ${ }^{\text {flox/- }}$ mice on a p53 null background will help to elucidate both the role of p53 and the mechanism of regulation of p21.

Involution of the mouse mammary gland has been extensively characterized morphologically and many genes are known to be switched on or off early during this process. Involution has been proposed to occur in two phases (Lund et al. 1996; Li et al. 1997). Initially, expression of milk protein genes is down-regulated, Stat3 is activated, and apoptosis modulating genes are regulated. Some epithelial cells undergo apoptosis and are shed into the alveolar lumina, but this phase is reversible if suckling is recommenced (Li et al. 1997). The gland then undergoes a second phase of irreversible destruction in which the lobuloalveolar compartment collapses and the basement membrane is proteolytically degraded (Talhouk et al. 1992; Lund et al. 1996).

Here we show that Stat3 activation is pivotal to the normal induction of involution. The mechanism of activation of Stat 3 remains unclear but may be due to accumulation of milk in the lumina and subsequent stretching of the epithelial cells (Pan et al. 1997). The signal for the second phase of involution was proposed to be a systemic drop in hormone levels, but clearly, in the BLG-Cre/Stat $3^{\text {flox/- }}$ mice gland remodeling is delayed, suggesting that the activation of the proteases is delayed. As the Cre recombinase is expressed specifically in the epithelial compartment, fully functional Stat3 will be present in the stromal cells (the source of the proteases; Lund et al. 1996). This suggests that either an essential Stat3-mediated signal is required from the epithelial to the mesenchymal cells or that a threshold level of apoptosis is necessary for protease activation.

We have shown that Stat3 is required for the normal program of apoptosis and involution in the mammary gland, and we propose that one target of Stat 3 in the induction of involution is IGFBP-5. We demonstrate the value of tissue-specific conditional knockout mice in enhancing our understanding of the in vivo role of developmentally regulated genes, particularly when constitutive knockouts result in embryonic lethality. Further studies will focus on in vivo and in vitro models to further unravel the mechanism of action and targets of Stat 3 in this process, and also the role of possible compensatory signals in the gland.

\section{Materials and methods}

Generation of mice and tissue for analysis

Mice with Stat3 deleted specifically in the mammary gland were generated by crossing mice with one null Stat 3 allele and one floxed Stat3 allele (Takeda et al. 1998) with mice expressing Cre under the control of the $\beta$-lactoglobulin milk gene promoter (Selbert et al. 1998). Mice were maintained on an outbred background, control BLG-Cre/Stat $3^{\text {flox/+ }}$ mice were obtained from the same colony segregating for the same combination of genotypes. Genotyping was confirmed by tail tipping with the primers CCTGAAGACCAAGTTCATCTGTGTGAC and CACACAAGCCATCAAACTCTGGTCTCC specific for exon 22 and 23 of Stat3 respectively, to detect wild-type and floxed Stat3, AGCAGCTGACAACGCTGGCTGAGAAGCT and ATCGCCTTCTAT CGCCTTCTTGACGAG specific for Stat3 and the neo resistance gene, respectively, to detect the null allele. BLG-Cre expression was confirmed with primers as described previously (Selbert et al. 1998). Adult female mice were mated and following parturition, litters were maintained with at least six pups. Pups were removed after 10 days to initiate involution. Females were culled by cervical dislocation at day 10 of lactation or after 2, 3, or 6 days of involution. Mammary glands were removed and either snap frozen in dry ice or fixed in formalin and embedded in paraffin for sectioning. Photographs of haematoxylin and eosin-stained sections and TUNEL staining were taken with the AxioHOME microscope (Zeiss) and Roche Image Manager program at 100×, 400×, and 1000× magnification (as indicated in figure legends).

\section{Southern analysis}

DNA extracted from frozen tissue was digested overnight with HindIII and subjected to Southern blotting as described previously (Selbert et al. 1998) with a probe to exons 16-17 of Stat3 (Takeda et al. 1998). The membrane was exposed to Kodak Biomax film and band intensities quantified with the Fujifilm FLA2000 PhosphorImager and Advanced Image Data Analyser program (Fuji).

\section{Western blot analysis}

Protein was extracted from frozen mammary glands and run on SDS-polyacrylamide gels as described previously (Philp et al. 1996). Equal loading of gels was checked by staining the blotted gel with coomassie blue $(0.1 \%)$. Membranes were incubated in blocking buffer (5\% Marvel in TBS with $0.1 \%$ Tween 20 ) for 1 hr. Antibodies were obtained as follows: Phosphorylated Stat3, Stat1, and phosphorylated Stat1 (New England Biolabs); Stat3, Stat5a, SGP-2, Bcl-x, and p21 (Santa Cruz); Bax (Pharmingen); keratin 18 KS18.04 (Progen); p53 with CM5 antibody (a gift from David Lane, Dundee, UK); WAP (a gift from Lothar Hennighausen, National Institutes of Health, Washington, D.C.). Specifically bound antibody was detected with horseradish peroxidaseconjugated secondary antibodies and ECL (Amersham) and recorded by X-ray film. Densitometry analysis was carried out with the Bio-rad Molecular Analyst GelDoc1000.

\section{EMSA of DNA-binding activity}

Nuclear extracts were prepared from mammary tissue and subjected to EMSA as described previously using the STM site (Philp et al. 1996)

\section{Immunohistochemistry}

Immunohistochemistry for Stat3 was carried out with a rabbit 
polyclonal antibody (sc482X, Santa Cruz Biotechnology) and the peroxide-based Envision + system (Dako Ltd, Cambridge UK). Sections were deparaffinized and subjected to antigen retrieval by microwaving for $3 \times 5 \mathrm{~min}$ in $10 \mathrm{~mm}$ citric acid buffer $(\mathrm{pH}$ 6.0). Endogenous peroxide activity was inactivated by incubation in $1 \%$ hydrogen peroxide in water for $20 \mathrm{~min}$. Sections were rinsed with TBS ( $25 \mathrm{~mm}$ Tris at $\mathrm{pH} 7.6,130 \mathrm{~mm} \mathrm{NaCl}$ ) and blocked with $20 \%$ normal swine serum in TBS for $20 \mathrm{~min}$. Sections were incubated for $1 \mathrm{hr}$ with primary antibody (diluted $1 / 1000$ in TBS plus 5\% normal swine serum), washed in TBS, and incubated with HRP-conjugated Envision polymer (diluted one half) for $35 \mathrm{~min}$. Sections were washed with TBS and incubated with diaminobenzidine $10.5 \mathrm{mg} / \mathrm{ml}$ in $48 \mathrm{~mm}$ Tris, 0.038 $\mathrm{M} \mathrm{HCl}, 10 \mathrm{~mm}$ imidazole at $\mathrm{pH} 7.6$ containing $0.02 \%$ hydrogen peroxide) for $7 \mathrm{~min}$. Sections were washed in TBS and then water, counterstained with hematoxylin, eosin, and Scotts tap water $(20 \mathrm{~mm}$ potassium bicarbonate, $0.167 \mathrm{M}$ magnesium sulfate), dehydrated, and mounted. Photographs were taken with the AxioHOME microscope (Zeiss) and Roche Image Manager program at $400 \times$ magnification.

\section{Assessment of apoptosis and area occupied by adipocytes}

Apoptotic cells were identified on hematoxylin and eosinstained slides by light microscopy and classical morphological criteria (condensation and fragmentation of chromatin, cell shrinkage/separation from neighbors; Wyllie al. 1980). A running mean was established and a minimum of 1300 cells were scored per section, split between at least 10 randomly chosen fields with the general morphometry (object) program at 1000× magnification on the AxioHOME microscope (Zeiss). All counts were checked independently and calculated as a percentage of the total cell count. TUNEL staining was carried out on formalin-fixed, paraffin-embedded sections with the ApopTag kit (Intergen, NY) according to the manufacturer's instructions. A running mean was established and a minimum of 1800 cells were scored per section, split between at least 15 randomly chosen fields with the general morphometry (object) program at 1000× magnification on the AxioHOME microscope (Zeiss). Sections were scored blind and calculated as a percentage of the total cell count. Area occupied by adipocytes was scored from hematoxylin and eosin-stained slides. The areas of adipocytes were defined as groups of unstained (white) cells. By use of the general morphometry (structure) program at $100 \times$ magnification on the AxioHOME microscope, these areas were drawn around and their area calculated as a percentage of the total area of the field of view. The average of two representative fields was used for each section.

\section{IGFBP-5 Western ligand blot analysis}

Mammary homogenates were subjected to Western blotting with ${ }^{125}$ I-labeled IGF-1 as described previously (Hossenlopp et al. 1986). Quantitative changes in IGFBP-5 concentrations were determined by ImageQuant analysis of a phosphoimage (Molecular Dynamics, Sunnyvale, CA).

\section{Acknowledgments}

This work was supported by an AICR grant. A.C. is a Royal Society University Research Fellow and C.W. is funded by the Cancer Research Campaign.

The publication costs of this article were defrayed in part by payment of page charges. This article must therefore be hereby marked 'advertisement' in accordance with 18 USC section 1734 solely to indicate this fact.

\section{References}

Adams, J.M. and S. Cory. 1998. The Bcl-2 protein family: Arbiters of cell survival. Science 281: 1322-1326.

Bovolenta, C., L. Testolin, L. Benussi, P.J. Lievens, and E. Liboi. 1998. Positive selection of apoptosis resistant cells correlates with activation of dominant negative STAT5. J. Biol. Chem. 273: 20779-20784.

Catlett-Falcone, R., T.H. Landowski, M.M. Oshiro, J. Turkson, A. Levitzki, R. Savino, G. Ciliberto, L. Moscinski, J.L. Fernandez-Luna, G. Nunez, W.S. Dalton, and R. Jove. 1999. Constitutive activation of Stat 3 signaling confers resistance to apoptosis in human U266 myeloma cells. Immunity 10: $105-115$.

Chida, D., H. Wakao, A. Yoshimura, and A. Miyajima. 1998. Transcriptional regulation of the beta-casein gene by cytokines: Cross-talk between STAT5 and other signaling molecules. Mol. Endocrinol. 12: 1792-1806.

Chin, Y.E., M. Kitagawa, K. Kuida, R.A. Flavell, and X.Y. Fu. 1997. Activation of the STAT signaling pathway can cause expression of caspase 1 and apoptosis. Mol. Cell. Biol. 17: 5328-5337.

DeTorres, C., F. Munell, I. Ferrer, J. Reventos, and A. Macaya. 1997. Identification of necrotic cell death by the TUNEL assay in the hypoxic-ischemic neonatal rat brain. 1997. Neurosci. Lett. 230: 1-4.

Duan, C. and D.R. Clemmons. 1995. Transcription factor AP-2 regulates human insulin-like growth factor binding protein-5 gene expression. J. Biol. Chem. 270: 24844-24851.

Duttaroy, A. J.F. Qian, J.S. Smith, and E. Wang. 1997. Up-regulated p21CIP1 expression is part of the regulation quantitatively controlling serum deprivation-induced apoptosis. $I$. Cell Biochem. 64: 434-446.

el-Deiry, W.S. 1998. p21/p53, cellular growth control and genomic integrity. Curr. Top. Microbiol. Immunol. 227: 121-137.

Feng, Z.W., A. Marti, B. Jehn, H.J. Altermatt, G. Chicaiza, and R. Jaggi. 1995. Glucocorticoid and progesterone inhibit involution and programmed cell death in the mouse mammary gland. J. Cell Biol. 131: 1095-1103.

Fukada, T., M. Hibi, Y. Yamanaka, M. TakahashiTezuka, Y. Fujitani, T. Yamaguchi, K. Nakajima, and T. Hirano. 1996. Two signals are necessary for cell proliferation induced by a cytokine receptor gp130: Involvement of STAT3 in antiapoptosis. Immunity 5: 449-460.

Fukada, T., T. Ohtani, Y. Yoshida, T. Shirogane, K. Nishida, K. Nakajima, M. Hibi, and T. Hirano. 1998. Stat3 orchestrates contradictory signals in cytokine-induced G1 to S cell-cycle transition. EMBO J. 17: 6670-6677.

Hadsell, D.L., N.M. Greenberg, J.M. Fligger, C.R. Baumrucker, and J.M. Rosen. 1996. Targetted expression of des(1-3) human insulin-like growth factor 1 in transgenic mice influences mammary gland development and IGF-binding protein expression. Endocrinology 137: 321-330.

Heermeier, K., M. Benedict, M.L. Li, P. Furth, G. Nunez, and L. Henninghausen. 1996. Bax and Bcl- $\mathrm{x}_{\mathrm{S}}$ are induced at the onset of apoptosis in involuting mammary epithelial cells. Mech. Devel. 56: 197-207.

Hossenlopp, P., D. Seurin, B. Segovia-Quinson, S. Hardouin, and M. Binoux. 1986. Analysis of serum insulin-like growth factor binding proteins using Western blotting: Use of the method for titration of the binding proteins and competitive binding studies. Analyt. Biochem. 154: 138-143. 
Howie, S.E.M., A.J. Sommerfield, E. Gray, and D.J. Harrison. 1994. Peripheral T lymphocyte depletion by apoptosis after CD4 ligation in vivo: Selective loss of CD44- and 'activating' memory T cells. Clin. Exp. Immunol. 95: 195-200.

Ihle, J.N. 1996. STATs: Signal transducers and activators of transcription. Cell 84: 331-334.

Jerry, D.J., C. Kuperwasser, S.R. Downing, J. Pinkas, C. He, E. Dickinson, S. Marconi, and S.P. Naber. 1998. Delayed involution of the mammary epithelium in BALB/c-p53(null) mice. Oncogene 17: 2305-2312.

Kumar, A., M. Commane, T.W. Flickinger, C.M. Horvath, and G.R. Stark. 1997. Defective TNF-alpha-induced apoptosis in STAT1 null cells due to low constitutive levels of caspases. Science 278: 1630-1632.

Lakins, J., S.A.L. Bennett, J.H. Chen, J.M. Arnold, C. Morrissey, P. Wong, J. O'Sullivan, and M. Tenniswood. 1998. Clusterin biogenesis is altered during apoptosis in the regressing rat ventral prostate. J. Biol. Chem. 273: 27887-27895.

Li, M.L., J.D. Hu, K. Heermeier, L. Hennighausen, and P.A. Furth. 1996. Apoptosis and remodeling of mammary gland tissue during involution proceeds through p53-independent pathways. Cell Growth Differ. 7: 13-20.

Li, M.L., X.W. Liu, G. Robinson, U. BarPeled, K.U. Wagner, W.S. Young, L. Hennighausen, and P.A. Furth. 1997. Mammaryderived signals activate programmed cell death during the first stage of mammary gland involution. Proc. Natl. Acad. Sci. 94: 3425-3430.

Liu, X.W., G.W. Robinson, and L. Hennighausen. 1996. Activation of Stat5a and Stat $5 b$ by tyrosine phosphorylation is tightly linked to mammary gland differentiation. Mol. Endocrinol. 10: 1496-1506.

Liu, X.W., G.W. Robinson, K.U. Wagner, L. Garrett, A. WynshawBoris, and L. Hennighausen. 1997. Stat5a is mandatory for adult mammary gland development and lactogenesis. Genes \& Dev. 11: 179-186.

Lund, L.R., J. Romer, N. Thomasset, H. Solberg, C. Pyke, M.J. Bissell, K. Dano, and Z. Werb. 1996. Two distinct phases of apoptosis in mammary gland involution: Proteinase-independent and -dependent pathways. Development 122: 181193.

Meraz, M.A., J.M. White, K.F. Sheehan, E.A. Bach, S.J. Rodig, A.S. Dighe, D.H. Kaplan, J.K. Riley, A.C. Greenlund, D. Campbell, K. CarverMoore, R.N. Dubois, R. Clark, M. Aguet, and R.D. Schreiber. 1996. Targeted disruption of the STAT1 gene in mice reveals unexpected physiologic specificity in the JAK-STAT signaling pathway. Cell 84: 431-442.

Migheli, A., A. Attanasio, and D. Schiffer. 1995. Ultrastructural detection of DNA strand breaks in apoptotic neural cells by in situ end-labelling techniques. J. Pathol. 176: 27-35.

Minami, M., M. Inoue, S. Wei, K. Takeda, M. Matsumoto, T. Kishimoto, and S. Akira. 1996. STAT3 activation is a critical step in gp130-mediated terminal differentiation and growth arrest of a myeloid cell line. Proc. Natl. Acad. Sci. 93: 3963 3966.

Neuenschwander, S., A. Schwart, T.L. Wood, C.T. Roberts Jr, L. Hennighausen, and D. Le Roith. 1996. Involution of the lactating mammary gland is inhibited by the IGF system in a transgenic mouse model. J. Clin. Invest. 97: 2225-2232.

Nickerson, S.C. 1989. Immunological aspects of mammary involution. J. Dairy Sci. 72: 1665-1678.

O'Connor. 1998. Survival factors and apoptosis. In Advances in biochemical engineering/biotechnology. (ed T.H. Scheper) vol. 62, pp. 138-162. Springer-Verlag, Berlin, Germany.

Oliver, S.P. and L.M. Sordillo. 1989. Approaches to the manipulation of mammary involution. J. Dairy Sci. 72: 1647-1664.
Pan, J., K. Fukuda, H. Kodama, S. Makino, T. Takahashi, M Sano, S. Hori, and S. Ogawa. 1997. Role of angiotensin II in activation of the JAK/STAT pathway induced by acute pressure overload in the rat heart. Cir. Res. 81: 611-617.

Philp, J.C., T.G. Burdon, and C.J. Watson. 1996. Differential activation of STATs 3 and 5 during mammary gland development. FEBS Lett. 396: 77-80.

Quarrie, L.H., C.P. Addey, and C.J. Wilde. 1996. Programmed cell death during mammary tissue involution induced by weaning, litter removal, and milk stasis. J. Cell. Physiol. 168: 559-569.

Selbert, S., D.J. Bentley, D.W. Melton, D. Rannie, P. Lourenco, C.J. Watson, and A.R. Clarke. 1998. Efficient BLG-Cre mediated gene deletion in the mammary gland. Transgenic Res. 7: 387-396.

Sheffield, L.G. and L.C. Kotolski. 1992. Prolactin inhibits programmed cell death during mammary gland involution. FASEB I. 6: A1184.

Skov, S., M. Nielsen, S. Bregenholt, N. Odum, and M.H. Claesson. 1998. Activation of Stat3 is involved in the induction of apoptosis after ligation of major histocompatibility complex class I molecules on human Jurkat T cells. Blood 91: 35663573.

Stahelin, B.J., U. Marti, L. Solioz, H. Zimmermann, and J. Reichen. 1998. False positive staining in the TUNEL assay to detect apoptosis in liver and intestine is caused by endogenous nucleases and inhibited by diethyl pyrocarbonate. $I$. Clin. Pathol.-Mol. Pathol. 51: 204-208.

Steele, R.C., A.M. Thompson, P.A. Hall, and D.P. Lane. 1998. The p53 tumour suppressor gene. Br. J. Surg. 85: 14601467.

Strange, R., F. Li, S. Saurer, A. Burkhardt, and R.R. Friis. 1992. Apoptotic cell death and tissue remodeling during mouse mammary gland involution. Development 115: 49-58.

Streuli, C.H., G.M. Edwards, M. Delcommenne, C.B.A. Whitelaw, T.G. Burdon, C. Schindler, and C.J. Watson. 1995. Stat5 as a target for regulation by extracellular-matrix. $J$. Biol. Chem. 270: 21639-21644.

Takeda, K., K. Noguchi, W. Shi, T. Tanaka, M. Matsumoto, N. Yoshida, T. Kishimoto, and S. Akira. 1997. Targeted disruption of the mouse Stat3 gene leads to early embryonic lethality. Proc. Nat1. Acad. Sci. 94: 3801-3804.

Takeda, K., T. Kaisho, N. Yoshida, J. Takeda, T. Kishimoto, and S. Akira. 1998. Stat3 activation is responsible for IL-6-dependent $\mathrm{T}$ cell proliferation through preventing apoptosis: Generation and characterization of $\mathrm{T}$ cell-specific Stat3-deficient mice. J. Immunol. 161: 4652-4660.

Talhouk, R.S., M.J. Bissell, and Z. Werb. 1992. Coordinated expression of extracellular matrix-degrading proteinases and their inhibitors regulates mammary epithelial function during involution. J. Cell Biol. 118: 1271-1282.

Taylor-Papadimitriou, J. and E.B.Lane. 1987. Keratin expression in the mammary gland. In The mammary gland: Development, function and regulation (ed. M.C. Neville and C.W. Daniel), pp. 181-215. Plenum Press, New York, NY.

Teglund, S., C. Mckay, E. Schuetz, J.M. vanDeursen, D. Stravopodis, D.M. Wang, M. Brown, S. Bodner, G. Grosveld, and J.N. Ihle. 1998. Stat5a and Stat5b proteins have essential and nonessential, or redundant, roles in cytokine responses. Cell 93: $841-850$.

Tenniswood, M., R.S. Guennette, D. Taillefer, and M. Moorbroek. 1994. The role of growth factors and extracellular matrix proteases in active cell death in the prostate. In Apoptosis in hormone-dependent cancers (ed. M. Tenniswood and H. Michna), pp 225-246. Springer-Verlag, Berlin, Germany. 
Chapman et al.

Tonner, E., M.C. Barber, M.T. Travers, A. Logan, and D.J. Flint. 1997. Hormonal control of insulin-like growth factor binding protein 5 production in the involuting mammary gland of the rat. Endocrinology 138: 5101-5107.

Travers, M.T., M.C. Barber, E. Tonner, L. Quarrie, C.J. Wilde, and D.J. Flint. 1996. The role of prolactin and growth hormone in the regulation of casein gene expression and mammary cell survival: Relationships to milk synthesis and secretion. Endocrinology 137: 1530-1539.

Walker, N.I., R.E. Bennett, and J.R. Kerr. 1989. Cell death by apoptosis during involution of the lactating breast in mice and rats. Am. J. Anat. 185: 19-32.

Wyllie, A.H., J.F.R. Kerr and A.R. Currie. 1980. Cell death: The significance of apoptosis. Int. Rev. Cytol. 68: 251-306.

Xu, X., K. Wagner, D. Larson, Z. Weaver, C. Li, T. Reid, L. Hennighausen, A. Wynshaw-Boris, and C. Deng. 1999. Conditional mutation of Brca1 in mammary epithelial cells results in blunted ductal morphogenesis and tumour formation. Nat. Gen. 22: 37-43.

Zamorano, J., H.Y. Wang, R. Wang, Y. Shi, G.D. Longmore, and A.D. Keegan. 1998. Regulation of cell growth by IL-2: Role of STAT5 in protection from apoptosis but not in cell cycle progression. J. Immunol. 160: 3502-3512. 


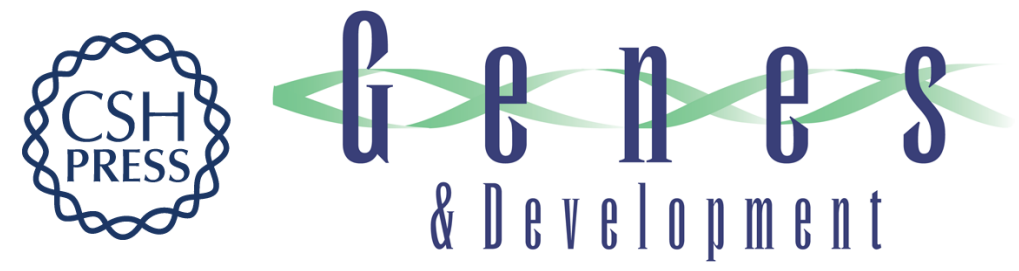

\section{Suppression of epithelial apoptosis and delayed mammary gland involution in mice with a conditional knockout of Stat3}

Rachel S. Chapman, Paula C. Lourenco, Elizabeth Tonner, et al.

Genes Dev. 1999, 13:

References This article cites 48 articles, 22 of which can be accessed free at:

http://genesdev.cshlp.org/content/13/19/2604.full.html\#ref-list-1

License

Email Alerting Receive free email alerts when new articles cite this article - sign up in the box at the top Service right corner of the article or click here.

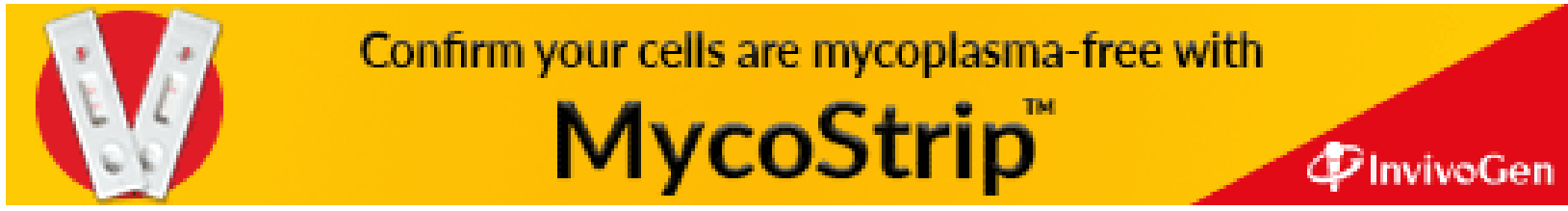

